AperTO - Archivio Istituzionale Open Access dell'Università di Torino

Sex identification of Eurasian Scops Owl Otus scops using morphometric analysis.

This is a pre print version of the following article:

Original Citation:

Availability:

This version is available http://hdl.handle.net/2318/1766496

since 2021-01-12T19:25:09Z

Published version:

DOI:10.1080/03078698.2019.1759914

Terms of use:

Open Access

Anyone can freely access the full text of works made available as "Open Access". Works made available under a Creative Commons license can be used according to the terms and conditions of said license. Use of all other works requires consent of the right holder (author or publisher) if not exempted from copyright protection by the applicable law. 


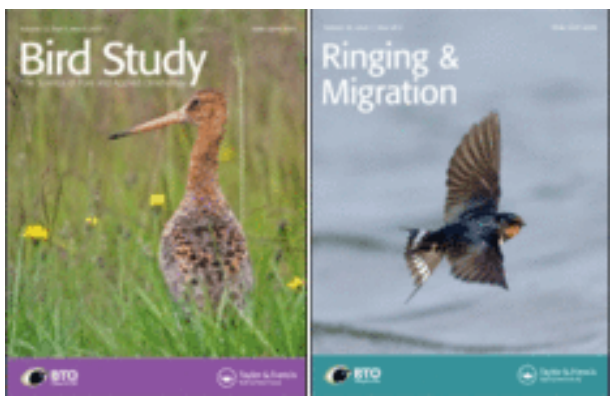

\section{Sex identification of Eurasian Scops Owl Otus scops using morphometric analysis.}

\begin{tabular}{|r|l|}
\hline Journal: & Bird Study/Ringing \& Migration \\
\hline Manuscript ID & RM-2020-002.R1 \\
\hline Manuscript Type: & Original Article \\
\hline Author: & 06-Apr-2020 \\
\hline Complete List of Authors: & $\begin{array}{l}\text { Boano, Giovanni; Museo Civico di Storia Naturale di Carmagnola } \\
\text { Tizzani, Paolo; University of Turin, Dipartimento di Scienze Veterinarie } \\
\text { Rasero, Roberto; University of Turin, Dipartimento di Scienze Veterinarie } \\
\text { Fasano, Sergio } \\
\text { Centili, Duccio } \\
\text { Silvano, Fabrizio; Museo Civico di Storia Naturale di Stazzano } \\
\text { Soglia, Dominga; University of Turin, Dipartimento di Produzioni Animali, } \\
\text { Epidemiologia ed Ecologia } \\
\text { Sacchi, Paola; University of Turin, Dipartimento di Scienze Veterinarie } \\
\text { Meneguz, Pier; University of Turin, Dipartimento di Scienze Veterinarie }\end{array}$ \\
\hline Keywords: & Scops owl, sexing, biometrics, molecular methods \\
\hline &
\end{tabular}

\section{SCHOLARONE" Manuscripts}


Sex identification of Eurasian Scops Owl Otus scops using morphometric analysis

Boano Giovanni', Tizzani Paolo², Rasero Roberto ${ }^{2}$, Fasano Sergio Giuseppe ${ }^{3}$, Centili Duccio $^{4}$, Silvano Fabrizio 5 , Soglia Dominga², Sacchi Paola², Meneguz Pier Giuseppe ${ }^{2}$

${ }^{1}$ Museo Civico di Storia Naturale, Via S. Francesco di Sales 188, I-10022 Carmagnola (TO), Italy

${ }^{2}$ Dipartimento di Scienze Veterinarie, Università di Torino, Largo P. Braccini 2, I-10090 Grugliasco (TO), Italy

${ }^{3}$ Fraz. San Bartolomeo 30, I-12062 Cherasco (CN), Italy

${ }^{4}$ Via A. Caroncini 51 - 00197 Roma, Italy

${ }^{5}$ Museo Civico di Storia Naturale, Villa Gardella Via Fossati 2, I-15060 Stazzano (AL), Italy

\begin{abstract}
The Eurasian Scops Owl Otus scops is a migratory owl whose population is declining throughout a large part of its breeding range, due to intensification of farming practices and land-use changes. For this reason, it is considered the most threatened owl in Europe. Several raptor species like Scops Owl present limited possibility to differentiate between sexes, due to the reduced biometric and morphometric differences. The availability of a reliable method to sex Scops Owl through biometric measurements would facilitate the study of sex-related survival, movements and behavior characteristics of this species, improving conservation management projects. In the current study, we developed a cost-effective and accurate method of sexing Scops Owl, based on discriminant analysis of morphometry. One hundred and five birds were captured, sexed using genetic methods and biometric measures were taken. A GLM model was built to evaluate the biometric measures statistically linked to the sex. The best model $(\mathrm{AIC}=49.211)$ selected three biometric measures: wing length, tail length, weight. The results of the model were used to derive models scores, and the predictive probability of male and female to be correctly identified was estimated. The discriminant function provides an accurate method of sexing Scops Owl in the hand.
\end{abstract}

\title{
INTRODUCTION
}


The Eurasian Scops Owl Otus scops (hereafter Scops Owl) is a migratory owl distributed as a breeding bird throughout the Southern Palearctic, from Portugal to Central Asia, with a Southern limit in North Africa; the species spends the winter period mainly in sub-Saharan Africa and, with limited numbers in southern Europe (Glutz von Boltzheim \& Bauer 1980, Cramp 1985, del Hoyo et al. 1999). The species has shown widespread declines throughout a large part of its Western European breeding range, especially in Switzerland (Arlettaz 1990, Arlettaz et al. 1991), Spain (Martinez et al. 2007) and Northern Italy (Galeotti \& Sacchi 2001, Treggiari et al. 2013), mainly due to intensification of farming practices and land-use changes (Sergio et al. 2009), so it was considered species of European Conservation Concern (BirdLife International 2004); but in the last years signs of local recovery (e.g. Caula \& Beraudo 2014, Boano \& Silvano 2015, Knaus et al. 2018) and even of spreading towards North (Mebs \& Nicklaus 2014) have been detected.

In ecology, the identification of sex in natural populations is useful in both theoretical studies and practical applications (Arcese \& Keller 2018). Survival and dispersal parameters can noticeably affect sex ratio (Székely et al. 2014), migration and wintering patterns (Brides et al. 2017), habitat selection (Ruckstuhl \& Neuhaus 2006), mating systems and life history traits (Liker \& Székely 2005, Liker et al 2014). It is well known that in several bird species the survival rate is higher in males (Lack 1966, Greenwood 1980), while natal and breeding dispersal are greater in females (Clarke et al. 1997). Sex-related differences have been highlighted also in some Strigiformes species in dispersion patterns (Hakkarainen 2002), winter distribution (Kerlinger \& Lein 1986), and survival (León-Ortega 2016).

Several methods are available to sex monochromatic birds, i.e. laparotomy, behaviour observations and voice analysis (Galeotti et al. 1997, Bourgeois et al. 2007). Moreover, DNA-based tests have been successfully applied to sex identification in many species (Griffiths et al. 1998, Sacchi et al. 2004, Morinha et al. 2012, Çakmak et al. 2017).

Biometric measurements are commonly taken during ringing operations (Cucco et al. 1999, Scebba 2001, Gordo et al. 2017), however, in absence of a standardized protocol, it remains problematic to use morphometric criteria for sex determination.

This is true for several raptor species that present limited biometric differences, and no differences at all by plumage between sexes (del Hoyo et al. 1994, 1999). In European owls only brood patch is considered a useful sexing criterium in breeding period, whereas minor biometric measurements could be useful for some species, and color differences are limited to the genus Asio (Baker 2016). In particular, according to Cramp \& Simmons (1985), only minor differences in bill length are observable in adult Scops Owl, whereas Martinez et al. (2002) state that, differences in 
coloration between sexes have not yet been described, and that only the females can be identified during the breeding season by the presence of the brood patch.

One successful approach to sex monomorphic bird in field studies involves discriminant analysis using morphological measurements (Balbontin et al. 2001, Bertellotti et al. 2002, Rodriguez \& Martinez 2016).

With the present study, we develop a cost-effective method of sexing Scops Owl, based on discriminant analysis of morphometrics. To have a correct attribution of sex, all samples collected were tested using a DNA molecular method, based on the analysis of two conserved CHD (chromohelicase-DNA-binding) genes, namely CHD-W and CHD-Z, located on the sex chromosomes of all non-ratite species (Sacchi et al. 2004). A simple, non-invasive way to obtain a source of DNA in wild birds is feather collection (Griffiths \& Tiwari 1995, Bello et al. 2001, Dai et al. 2015). Plucking feathers does not require special training and their easy storage allows biological sample preservation under most field conditions.

\section{METHODS}

\section{Study area and field protocols}

The study areas were located in Northern and Central Italy, near the northern limits of the Mediterranean climate zone, not far from the northern limits of the Scops Owl breeding range in Western Europe.

The northern one, the Special Area of Conservation and Special Protection Area "IT1180004 - Greto dello Scrivia" located in NW Italy, was in a riparian habitat along the Scrivia river between Villalvernia and Novi Ligure (Piemonte, Alessandria, $44^{\circ} 49^{\prime} \mathrm{N}, 8^{\circ} 50^{\prime} \mathrm{E} ; 100-110 \mathrm{~m}$ a.s.1.). The habitat is an old gravel bed of the Scrivia which has been invaded by shrubby vegetation and scattered woodlands, and single trees with much dead wood (mainly poplars Populus nigra and oaks Quercus robur) on a well-drained soil.

The second area in Central Italy was located within the protected WWF Italy reserve "Laguna di Orbetello" (Tuscany, Orbetello, $42^{\circ} 28^{\prime} \mathrm{N}, 11^{\circ} 11^{\prime} \mathrm{E}$; 0-2 $\mathrm{m}$ a.s.1.). It was located on an 8-km-long isthmus connecting the mainland with Mt. Argentario. Near the ringing area, there was an old Stone Pine (Pinus pinea) plantation, hay meadows with hedgerows and single trees such as Cork Oaks (Quercus suber) and Black Poplars, scattered buildings and a strip of Mediterranean scrubland along the coastline.

All the Scops Owls were captured as part of a national program established to ringing birds for population and migration monitoring in Italy (Spina \& Volponi 2008). 
Birds were captured in mist-nets scattered opportunistically in the habitat, all newly captured birds were ringed with metal rings, and aged, as adult or young (first calendar year), according to the criteria summarized by Demongin (2016). Five females captured during the breeding period (midMay-June) were sexed according to the presence of a brood patch (Cramp 1985, Martinez et al., 2002).

For each of 105 sampled birds, we recorded the maximum length of the wing chord, eighth primary, bill from skull, tarsus and weight. From the same birds, feathers were collected as a source of genomic DNA. The feathers were stored at room temperature in $90 \%$ ethanol until analysis.

\section{Genetic analysis}

For all the feathers, genomic DNA extraction and molecular sexing method were performed as described in Sacchi et al. (2004). Besides, seven known-sex (three males and four females) Scops Owl samples of skeletal muscle from the tissue collection of the Museo Civico di Storia Naturale di Carmagnola were used as control specimens for the sexing protocol.

\section{Biometric analysis}

Descriptive analysis was carried out to derive indicators for each biometric measurement and their differences between sexes were analyzed using $t$-test.

Finally, a Generalized Linear Model (GLM) with binomial distribution was applied to select the biometric measures (predictors) significantly associated with sex (dependent variable). Model selection was done using a backward stepwise approach, and the best model was selected using the Akaike's Information Criteria AIC criteria (Akaike 1973).

The probability of correct classification for male and female and the model scores were derived and plotted together, to evaluate model performance in discriminating sex based on the selected biometric measures.

Descriptive analysis was carried out with the package "psych" (Revelle, 2019). GLM and ttest was carried out using the functionalities contained in the basic R package (R Core Team, 2018). Significant level was considered for $\mathrm{p}<0.05$.

Jackknife procedure was applied to evaluate the accuracy of each coefficient. Average value of the coefficients (average), their confidence intervals (IC95), and standard error of the estimates (SE) are provided.

\section{RESULTS}

\section{Genetic analysis}


DNA was successfully amplified for all the reference samples. The amplicon analysis on agarose gel electrophoresis showed a unique band of about $380 \mathrm{bp}$ in male and female (Fig. 1); after Asp700I enzymatic digestion, as suggested by Sacchi et al. (2004), males showed the band of $380 \mathrm{bp}$ whereas the female amplicon was resolved into three bands (380, 280, and 100 bp) (Fig. 2). The restriction enzyme cuts CHD-W but not CHD-Z fragment. Results in reference samples validated the molecular sexing test in Otus scops species.

We collected feathers from 105 birds (33 juveniles, 68 adults and four not aged). Fifty-one birds resulted males and 54 females (five of which showed an evident brood patch). Among the juveniles, 19 were males and 14 were females. Among the adults, 30 were males and 38 females. Two males and two females not aged were discarded from the biometric analysis.

\section{Biometric analysis}

The descriptive indexes for the biometric measures, divided by male and female are presented in Table 1 for juveniles and in Table 2 for adults.

We did not find any significant differences in juvenile's biometric measures by sex ( $t$-test). Instead, strong significant differences in adult's biometric measures by sex were found for the wing, eight primary, tail and weight (t-test).

Considering that biometric differences were not significant in juveniles, statistical analysis focused on adult subjects only.

A generalized linear model (GLM) was used to select the variables significantly associated with sex. The best model $(\mathrm{AIC}=49.211)$ selected three biometric measures: wing, tail and weight. The results of the GLM are presented in Table $3 \mathrm{a}$.

Average value of the coefficients (average), derive from the jackknife procedure, their confidence intervals, and standard error of the estimates are provided in Table $3 b$.

The results of the model were used to derive model scores, and the predictive probability of male and female to be correctly identified was estimated. The model scores and the related predictive probabilities were plotted, to evaluate model performance and cut-off values to discriminate sex based on biometric measures (Fig. 3). A discriminant equation is provided below:

$$
\text { Score }=86.61138+(-0.27561 * \text { Wing })+(-0.37167 * \text { Tail })+(-0.20153 * \text { Weight })
$$

A $90 \%$ probability to correctly classify females and males is reached respectively for a score value below -2.19 and above 2.0. Setting these cut-offs, $100 \%$ of males and females having a model score in this range were correctly classified. This corresponds to $53 \%$ of all the females in the sample and $42 \%$ of all the males. Using less strict parameters and using $80 \%$ probability of correct classification, $59 \%$ of the females are correctly classified with no mistakes, and $50 \%$ of the males but including a wrong classification of 1 subject ( $8 \%$ of the animals selected). 


\section{DISCUSSION}

Our work is the first to show with genetically sexed birds that some biometric measures are certainly linked with sex and a discriminant function analysis (DFA) of wing, tail and weight can consistently sex, using an $80 \%$ cut-off probability, 55\% of Scops Owls. In general, the model has better performance in classifying the females rather than the males.

The DNA technique of Sacchi et al. (2004) was applied to Scops Owl for the first time and unambiguously sexed individual birds, confirming its usefulness in different avian species.

The discriminant functions produced through morphometry provided an accurate method of sexing Scops Owl in the hand.

Our study highlighted that sex discrimination based on the biometric approach according to measurements of wing, eight primary, tail and weight is possible and accurate only for adults, analyzed during spring and summer, as we only tested birds trapped from April to August. Birds captured just before or during migration could be heavier due to the important fat reserves, so including weight in the DFA needs to be controlled in other seasons. Contrary to the expectations, we did not find yet any significant sexual difference in our population in bill length observed in other samples (Cramp 1985).

It is worth noting that our sample is from a limited area of the Scops Owl breeding range and mainly from the northern boundary of the western part of the range. Although the biometric variations among Scops Owl European populations seem very little or negligible (Cramp 1985), it is known that also in species with relatively small geographic variation the discriminant function calculated for birds of different geographical origin could mis-sex different percentages of individuals (Palomares et al. 1997). So, we would suggest that applications of similar studies to other Scops Owl populations or in other periods of the year would be useful to better define the applicability of this sexing method.

The ability to determine the sex will be valuable in future studies addressing inter-sexual differences in migration patterns and winter distribution.

In conclusion, we propose a simple system to sex Scops Owls to be tested in other regions and seasons. The discriminant analysis described here uses only three variables, which are easily measured in the field, and provides classification with a high level of accuracy.

ACKNOWLEDGMENTS - Many people helped us during the fieldwork, and we especially thank Valter Bagnasco Piero Bravin, Alessandra Calcagno, Claudio Oddone, Lorenza Roncali and Silvio Varagnolo. We also thank "Laguna di Orbetello" Nature reserve of WWF-Italy with its former 
Director M. Carsughi for support and assistance. Kelsey Horvath kindly revised the English text. The referees suggestions greatly improved the paper. 


\section{REFERENCES}

Akaike, H. (1973) Information theory and an extension of the maximum likelihood principle. In Proceedings of the Second International Symposium on Information Theory, B. N. Petrov and F. Csaki (eds), 267-281. Budapest: Akademiai Kiado.

Arcese, P. \& Keller, L.F. (2018) Population Structure. In Ornithology: Foundation, Analysis and Application. Morrison, M.L., Rodewald, A.D., Voelker, G., Colòn, M.R. \& Prather, J.F.(eds). J. Opkins Univ. Press, Baltimore.

Arlettaz, R. (1990) La population relictuelle du Hibou petit-duc Otus scops en Valais central: dynamique, organisation spatiale, habitat et protection. Nos Oiseaux 40, 321-343.

Arlettaz, R., Fournier, J., Juillard, M., Lugon, A., Rosse, D. \& Sierro, A. (1991) Origines du declin de la population relictuelle du Hibou petit duc, Otus scops, dans les Alpes valaisannes (sud- ouest de la Suisse): une approche empirique. In: Juillard, M, Bassin, P., Baudvin, H., Genot, J.-C., Ravussin, P.-A. \& Rebetez, C. (eds). Rapaces nocturnes. Actes XXX Coll. Int. Orn. Nos Oiseaux, Porrentruy (Suisse), pp 15-30.

Balbontìn, J., Ferrer, M. \& Casado, E. (2001) Sex determination in Booted Eagle (Hieraaetus pennatus) using molecular discriminant function procedures and analysis. J. Raptor Res. 35, $20-23$.

Baker J. (2016) Identification of European Non-Passerines. BTO, Thetford.

Bello., N, Francino, O. \& Sanchez, A. (2001) Isolation of genomic DNA from feathers. J.Vet. Diag. Invest. 13, 162-164.

Bertellotti, M., Tella, J. L., Godoy, J.A., Blanco, G., Forero, M. G., Donazar, J.A. \& Ceballos O. (2002) Determining sex of Magellanic Penguins using molecular procedures and discriminant functions. Waterbirds 25, 479-484.

Birdlife International (2004) Birds in Europe: population estimates, trends and conservation status. BirdLife Int. Conserv. Ser. No.12, Cambridge, UK.

Boano, G. \& Silvano, F. (2015) Adult survival probability in a recovered population of Scops Owls Otus scops. Ardea 103, 145-153.

Bourgeois, K., Curé, C., Legrand, J., Gòmez-Diaz, E., Vidal, E., Aubin, T. \& Mathevon, N. (2007) Morphological versus acoustic analysis : what is the most efficient method for sexing Yelkouan Shearwaters Puffinus yelkouan? J. Ornithol. 148, 261-269.

Brides, K., Wood, K. A., Hearn, R. D. \& Fijen, T. P. M. (2017) Changes in the sex ratio of the Common Pochard Aythya ferina in Europe and North Africa. Wildfowl 67, 100-112. 
Çakmak, E., Pekşen, C.A. \& Bilgin, C-C. (2017) Comparison of three different primer sets for sexing birds. Journal of Veterinary Diagnostic Investigation 29, 59-63.

Caula, B., \& Beraudo, P. L. (2014) Ornitologia Cuneese. Indagine bibliografica e dati inediti. Primalpe, Cuneo, 694.

Clarke, A. L., Saether, B. E. \& Røskaft (1997) Sex biases in avian dispersal: a reappraisal. Oikos 79, 429-438.

Cramp, S. (ed.) (1985) The Birds of the Western Palearctic, Vol. IV, Oxford Univ. Press.

Cucco, M., Lingua, G., Bocchio, D., Acquarone, C. \& Malacarne, G. (1999) Sex identification in the Moorhen (Gallinula chloropus) by flow cytometry and morphometric analysis. Italian Journal of Zoology 66, 1-6.

Dai, Y., Lin, Q., Fang, W., Zhou, X. \& Chen, X. (2015) Noninvasive and non-destructive sampling for avian microsatellite genotyping: a case study on the vulnerable Chinese Egret (Egretta eulophotes). Avian Research 6, 1-9.

del Hoyo, J., Elliott, A. \& Sargatal, J. (eds.) (1994). Handbook of the Birds of the World. Vol. 2 New World Vultures to Guineafowl. Lynx Edicions, Barcelona.

del Hoyo, J., Elliott, A. \& Sargatal, J. (eds.) (1999). Handbook of the Birds of the World. Vol. 5. Barn-owls to Hummingbirds. Lynx Edicions, Barcelona.

Demongin, L. (2016) Identification Guide to the Birds in the Hand. Beauregard-Vendon.

Donohue, K. C. \& Dufty, A. M. (2006) Sex determination of Red-tailed Hawks (Buteo jamaicensis calurus) using DNA analysis and morphometrics. J. F. Ornithol. 77, 74-79.

Fridolfsson, A., \& Ellegren, H. (1999). A Simple and Universal Method for Molecular Sexing of Non-Ratite Birds. Journal of Avian Biology 30, 116-121. doi:10.2307/3677252

Galeotti, P., Sacchi, R. \& Perani, E. (1997) Cooperative defence and intrasexual aggression in Scops Owls (Otus scops): Responses to playback of male and female calls. - J. Raptor Res. 31, 353-357.

Galeotti, P. \& Sacchi, R. (2001) Turnover of territorial Scops Owls as estimated by spectrographic analyses of male hoots. Journal of Avian Biology 32, 256-262.

Glutz von Blotzheim, N. \& Bauer, K.M. (1980) Handbuch der Vögel Mitteleuropas, Bd. 9: Columbiformes, Piciformes. Akad.Verlagsgesellschaft, Wiesbaden.

Gordo, O., Arroyo, J. L., Rodríguez, R., \& Martínez, A. (2017) Inability of biometry to discriminate Iberian and Common Chiffchaffs during the autumn migration period. Ardeola 64, 49-66.

Griffiths, R, Daan, S. \& Dijkstra, C. (1996) Sex identification in birds using two CDH genes. Proc $R$ Soc Lond, Ser B 263, 1251-1256. 
Griffiths, R, Double, MC, Orr, K. \& Dawson, R.J.G. (1998) A DNA test to sex most birds. Mol Ecol. 7, 1071-5.

Griffiths, R., \& Tiwari, B. (1995) Sex of the last wild Spix's Macaw. Nature 375, 454.

Hakkarainen, H., Korpimäki, E., Koivunen, V. \& Ydenberg, R. (2002) Survival of male Tengmalm's Owls under temporally varying food conditions. Oecologia 131, 83-88.

Ito, H, Sudo-Yamaji, A, Abe, M, Murase, T. \& Tsubota, T. (2003) Sex identification by alternative polymerase chain reaction methods in Falconiformes. Zool Sci. 20, 339-344.

Kerlinger, P. \& Lein, M. R. (1986) Differences in winter range among age-sex classes of Snowy Owls Nyctea scandiaca in North America. Ornis Scandinavica 17, 1-7.

Knaus, P., Antoniazza, S., Wechsler, S., Guélat, J., Kéry, M., Strebel, N. \& Sattler, T. (2018) Schweizer Brutvogelatlas 2013-2016. Verbreitung und Bestandsentwicklung der Vögel in der Schweiz und im Fürstentum Liechtenstein. Sempach, Switzerland: Schweizerische Vogelwarte.

Lee, J. C.-I, Tsai, L.-C., Hwa, P.-Y., Chan, C.-L., Huang, A., Chin, S.-C., Wang, L.-C., Lin, J.T., Linacre, A. \& Hsieh, H.-M. (2010) A novel strategy for avian species and gender identification using the CHD gene. Molecular and cellular probes, 24, 27-31.

León-Ortega, M., del Mar Delgado, M., Martínez, J. E., Penteriani, V. \& Calvo, J. F. (2016) Factors affecting survival in Mediterranean populations of the Eurasian Eagle Owl. European journal of wildlife research 62, 643-651.

Liker, A., \& Székely, T. (2005). Mortality costs of sexual selection and parental care in natural populations of birds. Evolution 59, 890-897.

Martínez, J. A., Zuberogoitia, I., Martínez, J. E., Zabala, J. \& Calvo, J. F. (2007) Patterns of territory settlement by Eurasian Scops-Owls (Otus scops) in altered semi-arid landscapes. J. Arid Environ. 69, 400-409.

Martinez, J.A., Zuberogoitia, I. \& Alonso, R. (2002) Rapaces nocturnas: guia para la determinaciòn de la edad y el sexo en Estrigiformes Ibéricas. Monticola Editions, Madrid, Spain.

Mebs, T., \& Nicklaus, G. (2014) Die Brutvorkommen der Zwergohreule Otus scops in Deutschland. Ornithol. Anz., 53, 94-104.

Morinha, F., Cabral, J.A., \& Bastos, E. (2012) Molecular sexing of birds: a comparative review of polymerase chain reaction (PCR)-based methods. Theriogenology 78,703-714, ISSN 0093691X,https://doi.org/10.1016/j.theriogenology.2012.04.015.

Norris-Caneda, K.H. \& Elliott Jr., J.D. (1998) Sex identification in raptors using PCR. Journal of Raptor Research 32, 278-280. 
Palomares, L.E., Arroyo, B.E., Marchamalo, J., Sainz, J.J. \& Voslamber, B. (1997) Sex- and age-related biometric variation of Black-headed Gulls Larus ridibundus in Western European populations. Bird Study, 44, 310-317.

R Core Team (2018) R: A language \& environment for statistical computing. R Foundation for Statistical Computing, Vienna, Austria. URL https://www.R-project.org/.

Revelle, W. (2019). psych: Procedures for Psychological, Psychometric, and Personality Research. Northwestern University, Evanston, Illinois. R package version 1.9.12, https://CRAN.Rproject.org/package=psych.

Rodriguez, R., \& Martinez, A. (2016) Sexing of Phylloscopus based on multivariate probability of morphological traits. Ringing \& Migration 31, 83-97.

Ruckstuhl, K. \& Neuhaus, P. (eds.) (2006). Sexual segregation in vertebrates. Cambridge University Press.

Sacchi, P., Soglia, D., Maione, S., Meneguz, G., Campora, M., \& Rasero, R. (2004) A noninvasive test for sex identification in Short-toed Eagle (Circaetus gallicus). Molecular \& Cellular Probes 18, 193-196. doi:10.1016/j.mcp.2004.01.002

Scebba, S. (2001) Biometrics and sex ratios of Skylarks Alauda arvensis during migration in southern Italy. Ringing \& Migration 20, 364-370.

Sergio, F., Marchesi, L. \& Pedrini, P. (2009) Conservation of Scops Owl Otus scops in the Alps: relationships with grassland management, predation risk and wider biodiversity. Ibis 151, 4050.

Spina, F. \& Volponi, S. (2008) Atlante della Migrazione degli Uccelli in Italia. 1. non-Passeriformi. Ministero dell'Ambiente e della Tutela del Territorio e del Mare, Istituto Superiore per la Protezione e la Ricerca Ambientale (ISPRA). Tipografia CSR-Roma.

Székely, T., Liker, A., Freckleton, R. P., Fichtel, C. \& Kappeler, P. M. (2014) Sex-biased survival predicts adult sex ratio variation in wild birds. Proceedings of the Royal Society B: Biological Sciences 281, 20140342.

Treggiari, A. A., Gagliardone, M., Pellegrino, I. \& Cucco, M. (2013) Habitat selection in a changing environment: the relationship between habitat alteration \& Scops Owl (Aves: Strigidae) territory occupancy. Ital. J. Zool. 80, 574-585.

Wang, L. C., Severinghaus, L. L., Chen, C. T., Liu, L. Y., Pan, C. H., Huang, D., Lee, H. Y., Lir, J. T., Chin, S. C., Pu, C. E. \& Wang, C. H. (2008) Sex Identification of Owls (Family Strigidae ) Using Oligonucleotide Microarrays. J. Hered. 99, 187-192. 


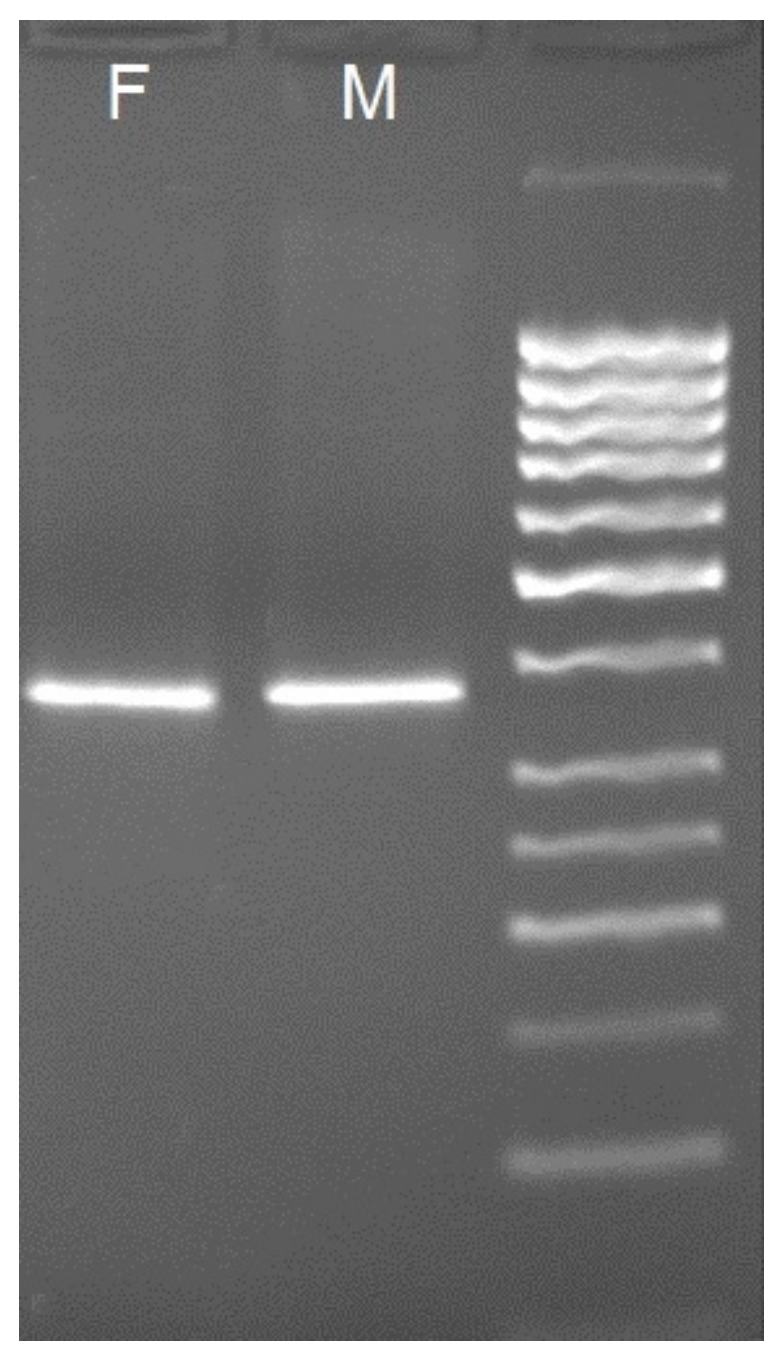

Figure 1. PCR product with P2-P8 PCR products were analysed by agarose gel electrophoresis $2 \%$ in TBE and visualised under UV light after ethidium bromide staining.: $F$, female; $M$, male; the last line is GeneRuler 50 bpDNA Ladder size standard, a unique band of about 380 bp results in all samples.

$75 \times 134 \mathrm{~mm}(96 \times 96 \mathrm{DPI})$ 


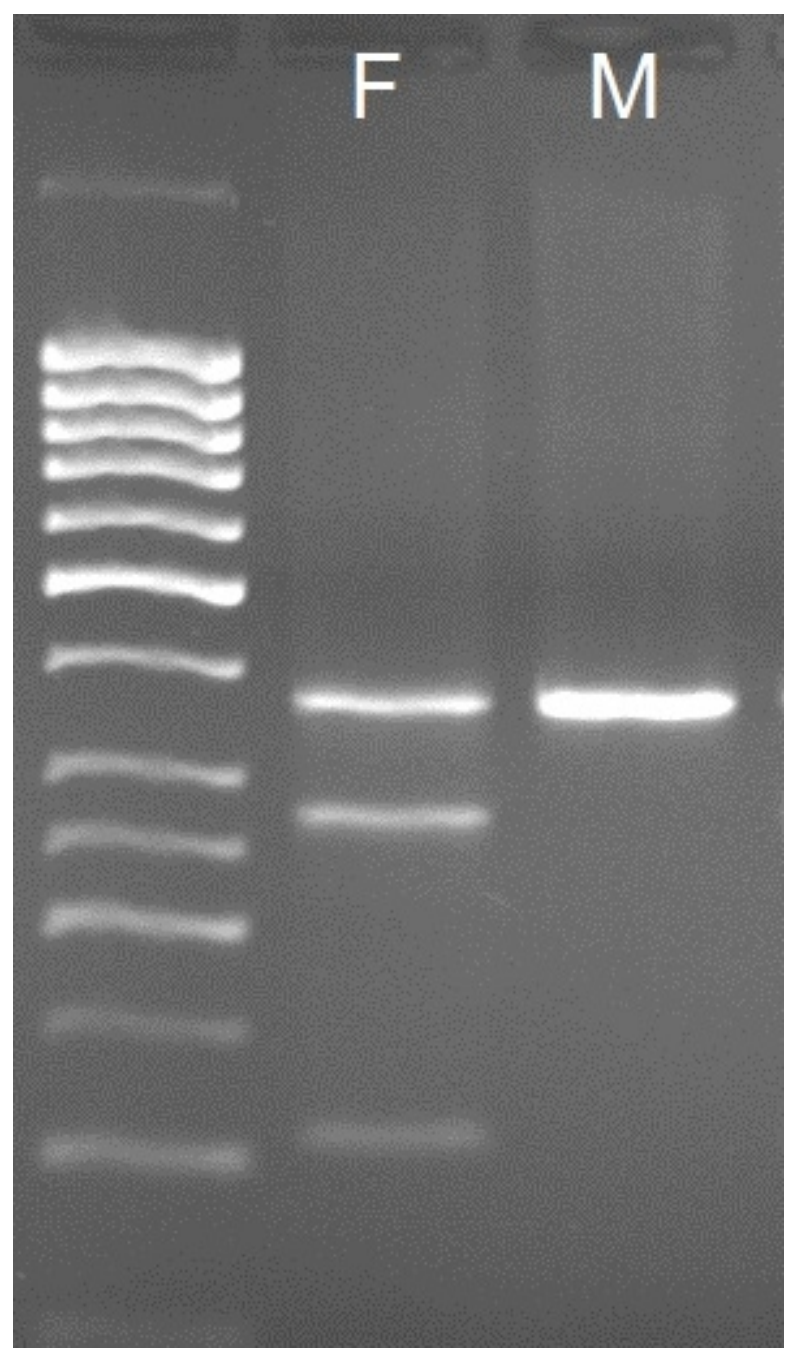

Figure 2. RFLP Asp700I Digestion products. Digestion products were analysed by agarose gel electrophoresis $2 \%$ in TBE and visualised under UV light after ethidium bromide staining.: $F$, female; $M$, male; the last line is GeneRuler 50 bpDNA Ladder size standard, an unique band results in male and three bands in female (380bp,280bp,100bp approximately).

$78 \times 135 \mathrm{~mm}(96 \times 96 \mathrm{DPI})$ 


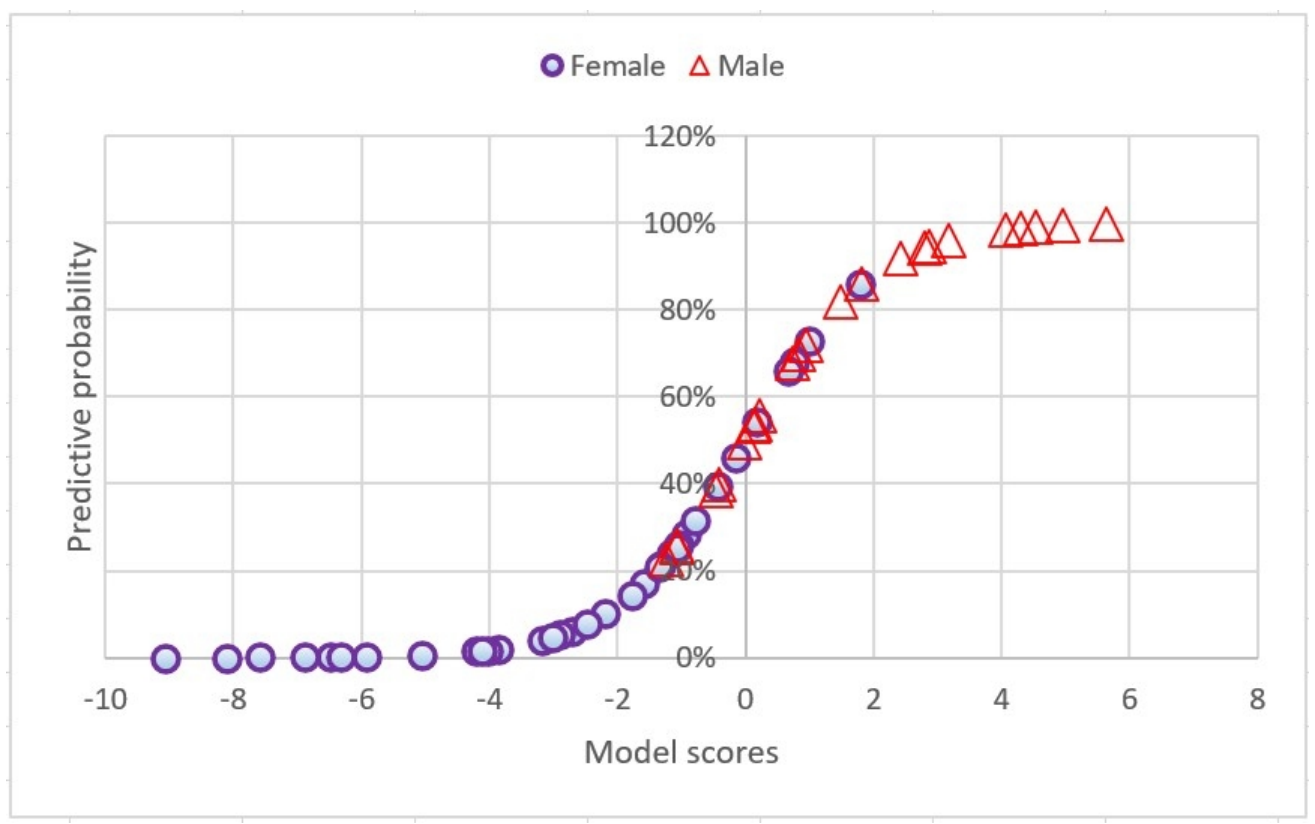

Figure 3. Model scores and probability of correct classification by sex.

$$
229 \times 143 \mathrm{~mm} \text { (96 x } 96 \text { DPI) }
$$




\begin{tabular}{l|c|c|c|cc|}
\hline Variable & Sex & Mean \pm sd & Range & $\mathrm{N}$ & $t$-test \\
\hline \multirow{2}{*}{ Wing } & $\mathrm{F}$ & $157.5 \pm 7.1$ & $140.0-167.0$ & 14 & $0.880(\mathrm{P}=0.3909)$ \\
& $\mathrm{M}$ & $155.7 \pm 3.4$ & $148.0-162.0$ & 19 & \\
$\mathbf{8}^{\text {th }}$ primary & $\mathrm{F}$ & $117.6 \pm 7.4$ & $94.0-125.0$ & 14 & $1.319(\mathrm{P}=0.2048)$ \\
& $\mathrm{M}$ & $114.8 \pm 3.3$ & $105.0-119.0$ & 19 & \\
Tail & $\mathrm{F}$ & $72.1 \pm 5.7$ & $61.0-81.5$ & 14 & $1.332(\mathrm{P}=0.2017)$ \\
& $\mathrm{M}$ & $69.9 \pm 2.2$ & $64.0-73.0$ & 19 & \\
Bill & $\mathrm{F}$ & $16.4 \pm 0.6$ & $15.5-18.0$ & 14 & $1.625(\mathrm{P}=0.1148)$ \\
& $\mathrm{M}$ & $16.0 \pm 0.7$ & $15.0-17.5$ & 19 & \\
Tarsus & $\mathrm{F}$ & $27.9 \pm 1.5$ & $25.6-31.3$ & 14 & $0.478(\mathrm{P}=0.6363)$ \\
& $\mathrm{M}$ & $28.1 \pm 1.6$ & $25.2-31.5$ & 19 & \\
Weight & $\mathrm{F}$ & $85.9 \pm 6.6$ & $76.0-99.8$ & 14 & $1.838(\mathrm{P}=0.0757)$ \\
& $\mathrm{M}$ & $81.0 \pm 8.7$ & $60.5-99.0$ & 19 & \\
\hline
\end{tabular}




\begin{tabular}{lccccc}
\hline Variable & Sex & Mean \pm sd & Range & $\mathrm{N}$ & $t$-test \\
\hline \multirow{2}{*}{ Wing } & $\mathrm{F}$ & $161.9 \pm 3.6$ & $155.0-169.5$ & 38 & $\mathbf{5 . 8 9 2}(\mathbf{P}<\mathbf{0 . 0 0 0 1})$ \\
& $\mathrm{M}$ & $156.4 \pm 4,0$ & $150.0-166.0$ & 30 & \\
8th primary & $\mathrm{F}$ & $119.1 \pm 3.1$ & $112.0-127.5$ & 36 & $\mathbf{4 . 4 6 7}(\mathbf{P}<\mathbf{0 . 0 0 0 1})$ \\
& $\mathrm{M}$ & $115.5 \pm 3.2$ & $110.0-121.0$ & 29 & \\
Tail & $\mathrm{F}$ & $71.4 \pm 2.3$ & $68.0-76.0$ & 37 & $\mathbf{3 . 4 0 7}(\mathbf{P}=\mathbf{0 . 0 0 1 4})$ \\
& $\mathrm{M}$ & $68.8 \pm 3.4$ & $60.0-76.0$ & 27 & \\
Bill & $\mathrm{F}$ & $16.5 \pm 0.9$ & $15.0-19.0$ & 35 & $0.908(\mathrm{P}=0.3680)$ \\
& $\mathrm{M}$ & $16.4 \pm 0.7$ & $15.0-17.7$ & 23 & \\
Tarsus & $\mathrm{F}$ & $27.6 \pm 1.9$ & $23.8-31.0$ & 38 & $0.634(\mathrm{P}=0.5286)$ \\
& $\mathrm{M}$ & $27.3 \pm 2,0$ & $23.7-32.0$ & 30 & \\
Weight & $\mathrm{F}$ & $92.0 \pm 11.2$ & $75.3-120.0$ & 38 & $\mathbf{6 . 2 0 8}(\mathbf{P}<\mathbf{0 . 0 0 0 1})$ \\
& $\mathrm{M}$ & $79.2 \pm 5.5$ & $68.0-92.0$ & 30 & \\
\hline
\end{tabular}




\begin{tabular}{lcccc}
\hline & Estimate & Std. Error & $\mathrm{z}$ value & $\operatorname{Pr}(>|\mathrm{z}|)$ \\
\hline (Intercept) & 86.6 & 26.44 & 3.28 & 0.001 \\
Wing & -0.3 & 0.12 & -2.26 & 0.024 \\
Tail & -0.4 & 0.20 & -1.87 & 0.061 \\
Weight & -0.2 & 0.08 & -2.62 & 0.009 \\
\hline
\end{tabular}




\begin{tabular}{|c|c|c|c|c|}
\hline \multirow{2}{*}{ Coefficients } & \multirow{2}{*}{ Average } & \multicolumn{2}{|c|}{ 95\% confidence interval } & \multirow{2}{*}{ SE } \\
\cline { 3 - 4 } & & Lower Bound & Upper Bound & \\
\hline Intercept & 86.91 & $86.41-$ & 87.41 & 0.5014 \\
\hline Wing & -0.28 & -0.28 & -0.27 & 0.0024 \\
\hline Tail & -0.37 & -0.38 & -0.37 & 0.0041 \\
\hline Weight & -0.20 & -0.20 & -0.20 & 0.0013 \\
\hline
\end{tabular}

